\title{
Scope of Supply Chain Management in Fruits and Vegetables in India
}

Rais $\mathbf{M}^{1 *}$ and Sheoran $\mathbf{A}^{2}$

${ }^{1}$ CSIR-National Institute of Science, Technology and Development Studies, Pusa Gate, KS Krishnan Marg, New Delhi, India

${ }^{2}$ Department of Civil Engineering, Birla Institute of Technology and Science, Pilani, Rajasthan, India

\begin{abstract}
India is the world largest producer of many fruits and vegetables but there still exist huge gap between per capita demand and supply due to enormous waste during post-harvest storage and handling caused by improper bagging without crating, lack of temperature controlled vehicles, unavailability of cold chain facilities in various parts of country for preserving the produce, along with significant processing of the agricultural produce which results in immense losses to the nation. Hence a proper supply chain management in fruits and vegetables has to be improved in all the stages of the supply by adopting best global practices in storage, packaging, handling, transportation, value added service etc to meet the country's demand of fruits and vegetables. As per this paper important drawbacks of the current supply chain are high level of wastage, quality degradation, poor infrastructural facilities and high cost. Government and private operators have to join hands to improve the physical infrastructure, information sharing and the service required for quality improvement of the supply chain.
\end{abstract}

Keywords: Fruits and vegetables; India; Wastage; Supply chain management

\section{Introduction}

India is the world's largest producer of many fresh fruits and vegetables, milk, major spices, fresh meat, few fibrous crops such as jute, several staples such as millets, castor oil seed etc. and ranked amongst the world's five largest producers of over $80 \%$ agricultural produce items, including many cash crops such as coffee and cotton [1]. Table 1 shows Production Share of major fruits and vegetables in World and Table 2 shows the ranking of India in world of the major fruits and vegetables. India's vast geographical area coupled with varied climate conditions facilitates to grow a variety of fruits and vegetables.

India produced around 81.285 MT fruits and 162.187 MTs of vegetables which accounts for nearly $14.0 \%$ of country's share in the world production of vegetables. Although, more than 70 types of vegetables are grown in our country, higher emphasis is given to more popular vegetables like tomato, brinjal, chilli, cauliflower, cabbage, peas, potatoes, onions and few common cucurbits and leafy vegetables. These also generate high income and employment, particularly for small farmers. Among the vegetables, potato is cultivated over large area followed by onion, tomato and brinjal whereas, in the case of production potato ranks first followed by tomato, onion and brinjal. Though India has lot many positives in the vegetable production and marketing sector, it has several disadvantages too. The country lacks an

\begin{tabular}{|l|c|c|l|c|}
\hline \multicolumn{4}{|c}{ Commodities } \\
\cline { 1 - 2 } Vegetables & India share \% & & Fruits & India share \% \\
\cline { 1 - 2 } Brinjal & 8.3 & & Apple & 2.4 \\
\hline Cabbage & 5.3 & & Banana & 32.6 \\
\hline Cauliflower & 4.9 & & Litichi & 0.7 \\
\hline Onion & 10.4 & & Citrus Fruits & 12.4 \\
\hline Peas & 2.5 & & Sapota & 1.8 \\
\hline Tomato & 11.2 & & Grapes & 3.1 \\
\hline Potato & 28.0 & & Mango & 22.1 \\
\hline Sweet Potato & 0.7 & & Papaya & 6.6 \\
\hline Tapioca & 4.5 & & Pineapple & 1.9 \\
\hline okra & 3.9 & & Guava & 3.9 \\
\hline others & 20.5 & & Others & 11.5 \\
\hline Cassava & 8 & & \\
\hline
\end{tabular}

Table 1: Production Share of major fruits and vegetables in World [1]. efficient supply chain for the distribution of the fruits and vegetables. Supply chain management plays an integral role in keeping business costs minimum and profitability as high as possible. There are many factors involved in supply chain management of which flow is one of the most important factor. Flow includes the product flow, the information flow and the finances flow. The product flow includes the movement of goods from a supplier to a customer, as well as any customer returns or service needs. The information flow involves transmitting orders and updating the status of delivery and the finance flow includes all the financial aspect such as invoices and payments. The present challenge in supply chain management is to maintain all three flows in an efficient manner, resulting in optimal results for farmers, growers, wholesalers and customers.

\begin{tabular}{|l|c|c|c|c|}
\hline \multicolumn{4}{|c|}{ Commodities } \\
\hline Vegetables & India Ranks & & Fruits & India Ranks \\
\hline Brinjal & 2 & & Apple & 10 \\
\hline Cabbage & 2 & & Banana & 1 \\
\hline Cauliflower & 2 & & Lemon & 2 \\
\hline Onion & 2 & & Citrus Fruits & 8 \\
\hline Peas & 1 & & Orange & 4 \\
\hline Tomato & 6 & & Grapes & 16 \\
\hline Potato & 3 & & Mango & 1 \\
\hline Sweet Potato & 9 & & Papaya & 5 \\
\hline Lettuce & 5 & & Pineapple & 5 \\
\hline Pumpkins/Gourda & 2 & & \\
\hline Beans & 6 & & & \\
\hline Cassava & 8 & & & \\
\hline
\end{tabular}

Table 2: Ranking of India in production of fruits and vegetables in World [7].

*Corresonding author: Mohammad Rais, CSIR-National Institute of Science, Technology and Development Studies, Pusa Gate, K.S. Krishnan Marg, New Delhi 110 012, India; E-mail: mohammad_rais@hotmail.com

Received January 27, 2015; Accepted February 16, 2015; Published February 23, 2015

Citation: Rais M, Sheoran A (2015) Scope of Supply Chain Management in Fruits and Vegetables in India. J Food Process Technol 6: 427. doi:10.4172/21577110.1000427

Copyright: (c) 2015 Rais M, et al. This is an open-access article distributed under the terms of the Creative Commons Attribution License, which permits unrestricted use, distribution, and reproduction in any medium, provided the original author and source are credited. 


\section{Indian Scenario of Fruits and Vegetables Production}

In India per capita availability of fruits and vegetables is quite low because of postharvest losses which account for about $25 \%$ to $30 \%$ of production. Table 2 shows the projected domestic demand of fruits and vegetables in India for the years 2010, 2015 and 2020 with 2010 as base year. Besides, quality of a sizable quantity of produce also deteriorates by the time it reaches the consumer. Most of the problems relating to the marketing of fruits and vegetables can be traced to their perishability. Perishability is responsible for high marketing costs, market gluts, price fluctuations and other similar problems. There is a rise of about $4 \%$ in the production of fruits and vegetables but there is significant increase in production area also which results in low per hectare production. Table 3 which show the total production of various fruits and vegetables in different states of India along with the area of production in the year 2013-14. This phenomenon is caused due to various factors in which economic and technological factors lead the race. State needs to educate the producers of the latest technology available and also help them by granting support to acquire them and proper supply chain management should be there in the country which would help prevention of exploitation of farmers and help increase their income.

\section{Population and demographic changes in India}

Indian middle and upper middle class population is growing very rapidly and there is also increase in number of young working couples, resulted in increase in demand for semi-processed food, fast foods, packed foods, ready-to-eat foods. Changing taste and preference towards consumption of basic foods items, which is driven by longer working hours, increase in double income families, more exposure to advertising, for comfort and convenience etc. Especially people living in cities are become more health and hygiene conscious. In place of conventional wet markets, they prefer to buy vegetables, fruits and other agri-products from the super markets and modern retail stores, and this leads to the entry of more and more corporates into the agri food marketing [2].

\section{Post harvest loss and their preventive measure}

The fruit and vegetable sector has grown substantially both in volume and in variety of outputs traded globally. Rising incomes, falling transportation costs, improved technologies and evolving international agreements, have all contributed to this level of growth. This increased level of fruit and vegetable production has, unfortunately, not been matched by developments in supply chain management, or by vertical integration of production with processing in many developing countries.

Processing activities are of critical importance to expansion and diversification within the fruit and vegetable sector in that they increase market opportunities for fresh fruits and vegetables and add value while minimizing postharvest losses. Furthermore, processing improves the viability, profitability and sustainability of fruit and vegetable production systems by increasing farm incomes, and generating rural employment and foreign exchange.

\begin{tabular}{|r|c|c|c|c|}
\hline \multicolumn{1}{|c|}{ Year } & \multicolumn{2}{|c|}{ Total Demand (million tonnes) } & \multicolumn{2}{c|}{ Per Capita Demand (kg) } \\
\hline & Fruits & Vegetables & Fruits & Vegetables \\
\hline Base year 2010 & 17.43 & 103.16 & 14.78 & 87.51 \\
\hline $\mathbf{2 0 1 5}$ & 21.06 & 119.12 & 16.67 & 94.28 \\
\hline $\mathbf{2 0 2 0}$ & 25.47 & 137.25 & 18.93 & 102.00 \\
\hline
\end{tabular}

Table 3: Projected domestic demand of fruits and vegetables in India [1].
Traditional processing technologies such as thermal processing (bottling and canning), freezing, dehydration (salting, brining and candying) drying, and fermentation are widely applied in the processing of fruits and vegetables at various levels (artisanal, intermediate and high) and scales (cottage, small, medium and large). Tropical juices and fruit pulps, canned pineapples, tomato paste and canned and dried mushrooms are examples of fruit and vegetable products produced using traditional processing technologies and which are increasingly entering in international trade. Dried and canned mushrooms produced in China, currently account for $52 \%$ of world trade in processed mushrooms, while canned pineapples produced in Thailand accounts for approximately $45 \%$ of that product in world trade.

Minimal processing technologies, specialized packaging and natural preservation systems are increasingly being applied in the preservation of fruits and vegetables for both developed and developing country markets, in response to growing consumer demand for convenience and for "fresh-like" fruits of high quality which are nutritious, flavorful and stable. These processing technologies focus on adding value with comparatively little product transformation while increasing product diversity.

While minimal and traditional processing technologies present considerable opportunities for innovation and vertical diversification in the fruit and vegetable sector, relatively few small and medium enterprises (SMEs) are able to tap into and benefit from these opportunities. Many SMEs lack the capacity to operate competitively in the current globalized market environment owing to problems of scale, the poor quality of input supplies, poor access to technology, limited technical expertise and research capacity, low production efficiency, high marketing cost, lack of knowledge and consequently inability to comply with international standards for processed products [3].

\section{Marketing of Fruits and Vegetables}

Marketing of horticultural crops is quite complex and risky due to the perishable nature of the produce, seasonal production and bulkiness. The spectrum of prices from producer to consumer,

which is an outcome of demand and supply of transactions between various intermediaries at different levels in the marketing system, is also unique for fruits. Moreover, the marketing arrangements at different stages also play an important role in price levels at various stages viz. from farm gate to the ultimate user. These features make the marketing system of fruits to differ from other agricultural commodities, particularly in providing time, form and space utilities. While the market infrastructure is better developed for food grains, fruits and vegetables markets are not that well developed and markets are congested and unhygienic.

\section{Different marketing channels}

- Producer-trader-wholesaler-retailer-consumer.

- Producer-trader-retailer-consumer.

- Producer-trader-consumer.

- Producer-consumer.

\section{An efficient marketing system can}

- Reduce post-harvest losses.

- Enhances farmers'realisation.

- Reduce consumer price. 
Citation: Rais M, Sheoran A (2015) Scope of Supply Chain Management in Fruits and Vegetables in India. J Food Process Technol 6: 427. doi:10.4172/2157-7110.1000427

Page 3 of 7

- Promote grading and food safety practices.

- Induce demand-driven production.

- Enable higher value addition.

- Facilitate export.

India is becoming an important market in the global fruit and vegetable trade

Competent Agri Solutions offers a full service consultancy cum supply chain Solutions Company covering the entire gamut of food and agricultural sector and sub-sectors with the fruit and vegetable trade in India as the main focus.

Competent AgriSolutions provides innovative farm to market supply chain solutions in retail and wholesale segments of fresh, frozen, fresh-cut and dehydrated Fruits \&Vegetables Its clients are established businesses, agri start-ups and overseas companies who wish to diversify or enter into Indian fresh produce trade or set up retail chains for perishable produce. The company also provides sourcing and marketing assistance, both for commodities and machinery / equipment, to organized retail, food processing companies and individuals in addition to being a technical advisory and project consultancy for larger infrastructure projects like wholesale produce markets, food parks and cold chain initiatives being undertaken under aegis of Indian Government agencies like NHB, MOFPI, NHM, NABARD etc. Competent Agri Solutions in also involved in project planning, introducing new products to the market and is also involved in linking small villages who produce fresh produce to enable then to supply large assured markets, particularly organized retailers. This help farmers increase their income by cutting out the middle man, improving productivity, reducing cost of production besides it producing higher quality fruit and vegetables due to less / improved handling across the supply chain [4].

\section{Supply Chain Management}

Supply Chain Management represents the management of the entire set of production, manufacturing/ transformations, distribution and marketing activities by which a consumer is supplied with a desired product. Supply chain management encompasses the planning and management of all activities involved in sourcing procurement, conversion, and logistics management. It also includes coordination and collaboration with channel partners, which may be suppliers, intermediaries, third-party service providers, or customers. Supply chain management integrates supply and demand management within and across companies [5]. Hence, supply chain management is defined as the design and operation of physical, management information and financial systems needed to transfer goods and services from point of production to point of consumption in an efficient and effective manner. The entire supply chain management process is a value chain where bottlenecks, value adding factors and liability factors are identified and addressed, thus enabling the retail organization to have an efficient supply chain. The supply is the part of retail operations that ensures that the right product is in the right place, at the right time and at the right cost. The supply chain perspective can help the retailers identify superior suppliers and distributors and help them to improve productivity, which ultimately brings down customers costs.

\section{Need for a supply chain in vegetable marketing}

Kalidas et al. says supply chain development not only benefits the private sector but also creates spin-offs that stimulate social, economic and environmental sustainable development in the region (employment generation, added value, minimization of product losses etc.) (Figure 1). The specific gains are:

- Reduction of product losses in transportation and storage.

- Increasing of sales.

- Dissemination of technology, capital and knowledge among the chain partners.

- Better information about the flow of products, markets and technologies.

- Transparency of the supply chain.

- Tracking and tracing to the source.

- Better control of product safety and quality.

- Large investments and risks are shared among partners in the chain.

- Productivity Improvement

- High customer satisfaction

- Increased profit

- On time delivery,

\section{Present scenario of supply chain in India}

It has been found that $30-40$ percent of fruits and vegetables are wasted due to post harvest losses. Table 4 shows the estimated waste percentages in each step of the food supply chain in India which is the cause of low availability of fruits and vegetables for consumers and the need for import of them in spite of India being second largest producer. There is lack of basic as well as specialized infrastructure such as cold storages, refer vans, cool chains, ripening chambers etc. Also there is a missing link between production and research system and consumers. The system lacks in capacity building market information, research and intelligence. India is short by 10 million tons of cold storage capacity due to which over 30 percent of agricultural produce goes waste every year, more than $20 \%$ of produce from fields is lost to poor postharvesting facilities and lack of cold chain infrastructure. India, the world's second largest fruit and vegetable producer encounters a waste of close to $25 \%$ worth of produce.

India has a huge opportunity to become a leading global food supplier if only it has an agile, adaptive, responsive and efficient supply chain. Some of the problems that are to be mentioned in Indian food supply chain are the presence of numerous stake holders which are working in isolation and the infrastructure connecting these partners

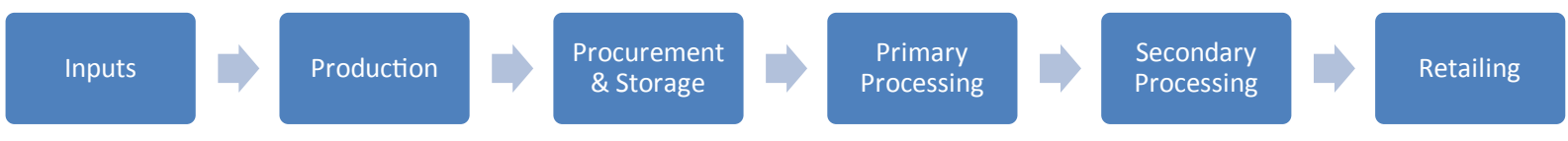

Figure 1: Supply chain in Fruits and Vegetables industries. 
Area in ' $000 \mathrm{Ha}$, Production in '000 MT

\begin{tabular}{|c|c|c|c|c|}
\hline \multirow[t]{2}{*}{ State/ut's } & \multicolumn{2}{|c|}{ Fruits } & \multicolumn{2}{|c|}{ Vegetables } \\
\hline & A & $P$ & A & $\mathrm{P}$ \\
\hline Andaman \& Nicobar & 3.55 & 29.72 & 6.89 & 51.79 \\
\hline Andhra Pradesh & 973.80 & 14219.31 & 710.31 & 12422.06 \\
\hline Arunachal Pradesh & 89.08 & 322.16 & 1.40 & 35.00 \\
\hline Assam & 153.96 & 2210.24 & 291.00 & 3479.94 \\
\hline Bihar & 306.73 & 4491.24 & 871.08 & 16572.70 \\
\hline Chhattisgarh & 212.88 & 1930.18 & 404.05 & 5502.36 \\
\hline D \& n Haveli & & & 1.10 & 5.50 \\
\hline \multicolumn{5}{|l|}{ Daman \& Diu } \\
\hline Delhi & & & 27.30 & 483.68 \\
\hline Goa & 11.27 & 81.61 & 6.67 & 80.86 \\
\hline Gujarat & 381.50 & 8413.17 & 571.30 & 11433.58 \\
\hline Haryana & 52.12 & 550.00 & 370.92 & 6000.00 \\
\hline Himachal Pradesh & 218.03 & 836.96 & 78.99 & 1514.43 \\
\hline Jammu \& Kashmir & 355.09 & 2073.74 & 63.06 & 1395.47 \\
\hline Jharkhand & 93.17 & 890.04 & 313.51 & 4236.73 \\
\hline Karnataka & 408.20 & 6936.90 & 439.20 & 7354.88 \\
\hline Kerala & 314.56 & 2584.01 & 146.00 & 3445.58 \\
\hline Lakshadweep & 0.22 & 0.48 & 0.25 & 0.33 \\
\hline Madhya Pradesh & 203.79 & 5691.90 & 631.25 & 12966.50 \\
\hline Maharashtra & 1565.00 & 10021.00 & 726.00 & 10112.00 \\
\hline Manipur & 54.05 & 525.78 & 24.28 & 274.50 \\
\hline Meghalaya & 33.59 & 339.36 & 42.04 & 428.04 \\
\hline Mizoram & 57.89 & 344.43 & 42.87 & 260.52 \\
\hline Nagaland & 40.16 & 375.74 & 52.48 & 483.39 \\
\hline Odisha & 325.86 & 2148.27 & 677.33 & 9433.66 \\
\hline Puducherry & 0.48 & 10.01 & 0.67 & 14.73 \\
\hline Punjab & 76.95 & 1528.61 & 190.42 & 3907.60 \\
\hline Rajasthan & 45.83 & 444.60 & 159.77 & 1366.09 \\
\hline Sikkim & 16.02 & 24.40 & 26.11 & 132.02 \\
\hline Tamilnadu & 328.54 & 7370.04 & 299.79 & 8678.49 \\
\hline Tripura & 60.57 & 638.78 & 45.58 & 760.16 \\
\hline Uttar pradesh & 328.70 & 5378.33 & 930.92 & 20341.04 \\
\hline Uttarakhand & 200.85 & 805.67 & 88.03 & 1059.57 \\
\hline West Bengal & 223.50 & 3194.00 & 1368.05 & 26014.95 \\
\hline Total & 7135.947 & 84410.673 & 9608.590 & 170248.15 \\
\hline
\end{tabular}

Table 4: Area and Production of fruits and vegetables 2013-14 [1]

is very weak. There is lack of demand estimation and technology applications such as cold chain logistic supply chains and product tracking and tracing. Lack system integration and presence of large number of unorganized retailers result in making unorganized supply chain practices further inefficient [6].

Deliya et al. [7] reported that the present supply chain that connects the farmers to both the organized, as well as the unorganized retail, is highly inefficient with several inter mediaries and manual handling. The result is lots of wastages as much as nearly $30 \%$ and also less remuneration for the farmers. Sudarshan naidu [8] says supply chain development not only benefits the private sector but also creates spin-offs that stimulate social, economical and environmental sustainable development in the region (employment generation, added value, minimization of product losses etc). The specific gains are reduction of product losses in transportation and storage, increasing of sales, dissemination of technology, capital and knowledge among the chain partners, better information about the flow of products, markets and technologies, transparency of the supply chain, tracking and tracing to the source, better control of product safety and quality, large investments and risks are shared among partners in the chain, productivity Improvement, high customer satisfaction, increased profit and on time delivery.

\section{Cold Storage}

\section{Status of cold storage and its potential in India}

The estimated annual production of fruits and vegetables in the country is about 130 million tones. This accounts for $18 \%$ of our agricultural output. Due to diverse agro climatic conditions and better availability of package of practices, the production is gradually rising. Although, there is a vast scope for increasing the production, the lack of cold storage and cold chain facilities are becoming major bottlenecks in tapping the potential. The cold storage facilities now available are mostly for a single commodity like potato, orange, apple, grapes, pomegranates, flowers, etc. which results in poor capacity utilization.

\section{Storage of fruits and vegetables and storage conditions}

Fruits and vegetables and many other commodities can be preserved by storage at low temperature, which retards the activities of microorganisms. Microorganisms are the spoilage agents and consist of bacteria, yeasts and molds. Low temperature does not destroy those spoilage agents as does high temperature, but greatly reduces their activities, providing a practical way of preserving perishable foods in their natural state which otherwise is not possible through heating. The low temperature necessary for preservation depends on the storage time required often referred to as short or long term shortage and the type of product. Table 5 shows desired storage environment of fruits and vegetables in the cold storage.

India has around 6,300 cold storage facilities, with a capacity of 30.11 million tones. However, some 75-80 per cent of these refrigerated warehouses are suitable only to store potatoes, a commodity that produces only 20 per cent of agricultural revenue. India needs expansion of cold storage infrastructure in an affordable, reliable and sustainable way to increase the contribution of agriculture to the economy.

\section{Cold chain investment}

India's investment in cold chain is projected to be $\$ 15$ billion over the next five years, IME pointed out. The report said that approximately 60 per cent of the total number of facilities is located only in Uttar Pradesh, Gujarat, West Bengal and Punjab. Only 4 million of the 104 million tons of fresh produce are transported through a cold chain.

\section{Wastage of fruits and vegetables}

It is reported that only $10-11$ per cent of the fruits and vegetables produced in India use cold storage. Storage capacity needs to be increased by 40 per cent to avoid wastage. There is more wastage of fruits and vegetables in the southern and western regions of India due to the tropical and humid climate.

\section{Role of cold storages}

The importance of cold storage of fruits and vegetables has to

\begin{tabular}{|l|c|c|c|c|c|}
\hline Commodity & Agricultural & Post harvest & $\begin{array}{c}\text { Processing } \\
\text { and } \\
\text { Packaging }\end{array}$ & Distribution & consumption \\
\hline & Production & \multicolumn{4}{|c|}{ handling and storage } \\
\hline $\begin{array}{l}\text { Fruits and } \\
\text { Vegetables }\end{array}$ & $15 \%$ & $9 \%$ & $25 \%$ & $10 \%$ & $7 \%$ \\
\hline
\end{tabular}

Source: Global Food Losses and Food Waste: Extent, Causes and Prevention, FAO, 2011

Table 5: Estimated/assumed waste percentages in each step of the FSC in India. 
Citation: Rais M, Sheoran A (2015) Scope of Supply Chain Management in Fruits and Vegetables in India. J Food Process Technol 6: 427. doi:10.4172/2157-7110.1000427

Page 5 of 7

achieve following objectives [9].

Seasonal production: The production of fruits and vegetables is highly located in favored situations of soil and climate. While the demand for fresh fruits and vegetable continuous almost throughout the year, their supplies are only seasonal. For e.g. apples grown in Jammu and Kashmir and Himachal Pradesh find markets all over the county. Therefore, cold storages have more importance in storing and supplying the seasonal fruits and vegetables.

Spoilage: A crucial problem faced in the case of fruits and vegetables is that of the huge enormous losses that occur on account of spoilage. The loss of spoilage on different stages on marketing estimated between $20 \%$ to $33 \%$ of the total production. There is an urgent need to minimize the present spoilage loss through cold storages.

Losses in transit: Most of the fruits and vegetables are of extremely perishable nature and cannot be kept long under ordinary conditions of storage. Refrigerated trucks and air-cooled wagons which will help in minimizing losses is transport.

Better distribution and fair prices: The prices paid by the consumer to the producer is very low ranging from $40 \%-60 \%$ one of the principal reasons for this is prevalence of various malpractices in the fruits and vegetables in terminal markets like Mumbai, Chennai, Delhi, Calcutta etc. These markets receive large quantities of fresh fruits from outside the state. The producer never knows at what price his product was in the nearest cold stores and gets fair prices with better distribution.

Stabilizing market prices: Besides the role of stabilizing market prices and also distributing both on demand basis and time basis. The farmers get opportunity of producing cash crops to get fair prices at the same time, the consumers get the supply of perishable fruits and vegetables with minimum prices i.e. cold storages stabilizing market prices of fruits and vegetables.

Maintain quality: Cold storages will help to maintain the quality of product for some period of time. It gives a chance to protect the quality of perishable goods for long time whenever it needed to store.

Wastage reduction: The cold storage system will greatly help in reducing the wastage of perishable goods. Generally the perishable goods wastage is more due its nature of short life and lack of storing facilities. Therefore the cold storage has a greater role in reduction of wastage.

Though India has lot many positives in the vegetable production and marketing sector, it has several disadvantages too. The country lacks an efficient supply chain for the distribution of the fruits and vegetables and cold storage being the central point. Cold storage helps in increasing the consumption life and processing helps in preservation of fruits and vegetables which can be consumed during off season.

\section{Factors affecting India's Supply Chain Management}

\section{Availability of cold storage}

Total no of cold storages in India is 6000 . With the total installed capacity of 25.5 million MT. Uttar Pradesh ,Maharashtra, West Bengal, Punjab and Gujarat account for more than $60 \%$ cold storage capacity followed by Andhra Pradesh, Haryana and Madhya Pradesh. Shown on Tables 6 and 7 are number of cold storages in India from 1986 to 1995 and number of cold storages and its capacity in selected states in 2013 respectively

\begin{tabular}{|l|c|c|}
\hline \multicolumn{1}{|c|}{ Commodity } & Temperature $\left.\mathbf{~}^{\circ} \mathbf{C}\right)$ & Relative Humidity (\%) \\
\hline Apple & $-1-3$ & $90-98$ \\
\hline Apricots & $-0.5-0$ & $90-95$ \\
\hline Avocado & $7-13$ & $85-90$ \\
\hline Asparagus & $0-2$ & $95-97$ \\
\hline Beans, green & $4-7$ & $90-95$ \\
\hline Beet root & $0-2$ & $95-97$ \\
\hline Broccoli & $0-2$ & $90-95$ \\
\hline Black berry & $-0.5-0$ & $95-97$ \\
\hline Cabbage & $0-2$ & $90-95$ \\
\hline Carrots & $0-2$ & $90-95$ \\
\hline Cauliflower & $0-2$ & $90-95$ \\
\hline Cherries & $0.5-0$ & $90-95$ \\
\hline Cucumber & $7-10$ & $90-95$ \\
\hline Brinjal & $0-2$ & $90-95$ \\
\hline Grapes & $-1-1$ & $85-90$ \\
\hline Lemons & $4-15$ & $86-88$ \\
\hline Lettuce & $0-1$ & $95-98$ \\
\hline Lime & $3-10$ & $85-90$ \\
\hline Mango & $11-18$ & $85-90$ \\
\hline Melon water & $2-4$ & $85-90$ \\
\hline Orange & $0-10$ & $85-90$ \\
\hline Peach & $-1-1$ & $88-92$ \\
\hline Potato & $1.5-4$ & $90-94$ \\
\hline & & \\
\hline
\end{tabular}

Table 6: Desired Storage Environment of Fruits and Vegetables in the cold storage.

\begin{tabular}{|c|c|c|}
\hline Year & $\begin{array}{c}\text { No. of Cold } \\
\text { Storages }\end{array}$ & $\begin{array}{c}\text { Installed Capacity in } \\
\text { '000MT' }\end{array}$ \\
\hline 1995 & 83 & 43 \\
\hline 1960 & 359 & 305 \\
\hline 1965 & 600 & 682 \\
\hline 1970 & 1218 & 1638 \\
\hline 1975 & 1615 & 1994 \\
\hline 1979 & 2266 & 3348 \\
\hline 1986 & 2607 & 5402 \\
\hline 2004 & 4748 & 19552 \\
\hline 2006 & 5101 & 21694 \\
\hline 2007 & 5316 & 23334 \\
\hline 1979 & 6000 & 25500 \\
\hline 1986 & 2266 & 3348 \\
\hline & 2607 & 5402 \\
\hline
\end{tabular}

Table 7: Number of Cold Storages in India [9].

The growth of the cold storages in India from 1955 to 2008 has not uniform, Region wise and State wise also. Region wise no. of cold stores in India are - Central Region -352 (6\%), South Region-778 (7\%), East Region-947 (33\%), North Region -2386 (47\%) and West Region -853 (7\%) at the end of the 2007 (Table 8).

The above tables reveal that the no of cold storages in India and Maharashtra in selected areas. Among the states Uttar Pradesh state having more than 1500 cold storages with the capacity of 1011800 $\mathrm{Mt}$, remain other states have less than 500 Cold storages. Within the Maharashtra the districts like thane, Mumbai and Nasik having the highest no of cold storages with 75 and 71 respectively.

\section{Government policies}

The Governments play a leading role in formulating the policies for food and agriculture which includes farming, production, processing, distribution besides the financing and retailing these activities. There 


\begin{tabular}{|l|l|c|c|c|}
\hline Sr. No & $\begin{array}{l}\text { Name of the } \\
\text { State }\end{array}$ & $\begin{array}{c}\text { Number. of } \\
\text { Cold storages }\end{array}$ & $\begin{array}{c}\text { Percentage } \\
\text { (\%) }\end{array}$ & $\begin{array}{c}\text { Capacity } \\
\text { (In M.T.) }\end{array}$ \\
\hline 1 & Uttar Pradesh & 1589 & 29.53 & 10118000 \\
\hline 2 & Maharashtra & 466 & 8.66 & 546748 \\
\hline 3 & West Bengal & 463 & 8.60 & 5682000 \\
\hline 4 & Punjab & 422 & 7.84 & 1345193 \\
\hline 5 & Gujarat & 398 & 7.40 & 1267304 \\
\hline 6 & Andhra Pradesh & 290 & 5.40 & 900606 \\
\hline 7 & Bihar & 246 & 4.57 & 1147041 \\
\hline 8 & Hariyana & 244 & 4.53 & 393121 \\
\hline 9 & Madhya Pradesh & 197 & 3.66 & 808052 \\
\hline 10 & Others & 1066 & 19.81 & 2242587 \\
\hline Total & & 5381 & 100 & 24450652 \\
\hline
\end{tabular}

Table 8: Number of Cold Storages and its Capacity in Selected States 2013 [9]

are several multitudes of departments handled between both State and Central Governments. In view of the globalization of this industry, the decisions if are mutually reinforcing and consistent would be extremely productive. Further research initiated in various other fields of food and agriculture may be helpful to further strengthen our economy.

\section{Connectivity}

Transferring goods from one place to connectivity plays a vital role in its successful implementation. In India the road infrastructure is not so good so transferring food and other goods is a real big challenge. Thus to improve the efficiency of food supply chain more attention is needed in this aspect.

\section{Sorting and grading technology}

The sorting and grading methodology needs to be updated technically as farmers do it themselves and they have very little knowledge about the processes. To improve the efficiency of the supply chain we need to improve the skills of the farmers.

\section{Handling and packaging}

Most of the agriculture is in remote village areas and all the places are not provided with proper facilities of handling and packaging. Because of this lot of fruits and vegetables are getting spoiled, wasted and quality deteriorated to be used in supply chain. Thus proper training and knowledge is required to be given to these people.

\section{Skilled labor}

Government should provide some training program on regular basis and may also build some institutions which provide scientific training in all the above aspects.

\section{Linkage in marketing channel}

Proper marketing and its information on other factors needs to be properly available for providing good efficiency for food supply chain and thus development of strong economy.

\section{Problems in Indian food supply chain}

India has a huge opportunity to become a leading global food supplier if only it has an agile, adaptive, responsive and efficient supply chain. Some of the problems that are to be mentioned in Indian food supply chain are:

- Numerous stake holders working in isolation: The food supply chain is complex with perishable goods and numerous small stake holders. In India, the infrastructure connecting these partners is very weak.
- Lack of demand estimation: Demand forecasting is totally absent and the farmers try to push whatever they produce into the market.

- Lack of technology applications: Cold chain logistic supply chains should take advantage of technology improvements in data capture and processing, product tracking and tracing, synchronized freight transport transmit times for time compression along the supply chain and supply-demand matching.

- Lack of system integration: The supply chain needs to be designed and built as a whole in an integrated manner. The process of new product development, procurement and order to delivery processes should be well designed and well supported with the help of IT tools and software.

- Presence of large number of unorganized retailers: At present the unorganized retailers are linked with farmers through wholesalers or commission agents. The commission agents and wholesalers redundant supply chain prac tices make unorganized further inefficient.

\section{Measures for improving supply chain and its effectiveness}

Deliya et al. has recommended the following measures: There has to be structural changes at different levels - farmers, intermediaries and consumer. The government, private, public-private partnership, cooperatives, technology providers, and even media can play a crucial role. Infrastructure like roads, transport, information and communication technology and cold storage are basic requirement for better results in Supply chain.

1. Demand forecasting is one of the important requirements for improving SC effectiveness. Due to poor forecasting, there is a imbalance between supply and demand. In some months vegetables are either not plucked from the farm due to lack of demand. In some reasons, produce is not available and a result, prices are boost up.

2. The Department of Horticulture acts as the facilitator for creation of infrastructure facilities for marketing of fruits and vegetables in the state. The Department of Agricultural Marketing is facilitating the marketing of agricultural/horticultural produces in the state. The Department of Agricultural Marketing recently established Raithra Santhe wherein the growers/farmers can bring their fruits and vegetables to the market and sell them directly to the growers. The Department of Agricultural Marketing is also handles the notified Fruits and Vegetables in the state through APMCS.

3. Vertical coordination of farmers through cooperatives, contract farming and retail chains would facilitate better delivery of output, reduce market risks, provide better infrastructure, attract more public interest, acquire better extension services, and create awareness regarding the prevailing and new technologies.

4. Customized logistics is another important immediate requirement to make logistic effective. This reduces the cost, facilitates the maintenance of quality of the produce and fulfills the requirements of targeted customers.

5. The State Government is providing subventions of Rs.1/- per $\mathrm{KWH}$ of electricity consumed by cold storages in the horticulture sector. Further, National Horticulture Board is providing a back ended subsidy of $25 \%$ (maximum of Rs.50 lakhs whichever is less) for construction/modernization of cold storage units. Cold storages are classified as Agro Food Processing Industry for providing incentives and concessions available to Agro Food Industry. 
Citation: Rais M, Sheoran A (2015) Scope of Supply Chain Management in Fruits and Vegetables in India. J Food Process Technol 6: 427. doi:10.4172/2157-7110.1000427

Page 7 of 7

6. Information system for better coordination among different stakeholders from farmers to consumers is the need of the hour. The internet and mobile communication can also be used to enable information and financial transfer between the stakeholders.

7. Public private partnership is another strategic solution. Supply chain like washing, waxing, grading, sorting, packing, pre-cooling, handling facilities, insurance, finance, transport and processing facilities would add value to supply chain functioning.

8. The main objective of establishing Food and Technology Parks it to promote agro and processing industries in cluster in area where there is predominant production of process able agriculture and Horticulture Products. These parks will also provide the required infrastructural and common facilities which are essential for sustenance of the industries. Quality assurance laboratories, Ware housing including cold storages, common effluent treatment plants etc.

\section{Conclusion}

There is a colossal waste during the post-harvest storage and handling due to improper bagging without crating, lack of temperature controlled vehicles, no cold chain facilities for preserving the produce, coupled with significant processing of the agricultural produce resulting in enormous losses to the nation. Given the characteristics of fruits and vegetables such as perishability, seasonality, bulkiness and delicate nature of the products coupled with inadequate storage and transport facilities, the supply chain can be made efficient by reducing the length of the chain improving cold chain facilities. The supply chain management in vegetables has to be improved in all the stages of the supply by adopting global best practices in storage, packaging, handling, transportation, value added service etc. And also by disintermediation and participation of organized players i.e., modern supply chain with a view to benefit both farmers as well as ultimate consumers. Several initiatives can be taken by the Indian government to solve the problems existing in the Indian food supply chain which includes allowing more organized retailers to enter into retail market, setting up of basic production factors, an optimal crop management system, developing a post-harvest infrastructure, entrepreneurial management and expertise and logistical infrastructure and finally by improving post-harvest operations related to handling, storage, and marketing of produce. All these initiatives will ensure consistency in supply and provide recorded and demonstrated traceability of products will benefit the farmers with good remunerative price and consumers with good quality produce and also will reduce the losses incurred due to poor post-harvest management and thereby ensuring adequate supply to the consumers. Creation of proper fruit and vegetable supply chain system will link together farmers, vegetable vendors, farmer's self-help groups and women vegetable/fruits vendors ensuring the availability of quality produce at competitive price to consumers at a convenient time and place.

\section{References}

1. National Horticulture Board.

2. Halder P, Pati S (2011) A need for paradigm shift to improve supply chain management of fruits and vegetables in India. Ideas 1: 1-20.

3. Rolle RS (2005) Postharvest Management of Fruit and Vegetables in the AsiaPacific Region.

4. Lilly V (2013) Marketing of Fruits and Vegetables in India- an Overview, PARIPEX. Indian Journal of Research 3: 9-20.

5. Kalidas K, Jiji S, Sureka M (2014) Supply Chain Management in Vegetables, Paripex. Indian Journal of Research 3: 315-316.

6. Bhardwaj S, Palaparthy I (2008) Factors Influencing Indian Supply Chains of fruits and Vegetables: ALiterature Review. The IUP Journal of Supply Chain Management, V: 59-68.

7. Deliya M, Thakor C, Parmar B (2012) A Study on differentiator in Marketing of fresh fruits and Vegetables from Supply Chain Management Perspective. Abhinav: National monthly Refered Journal of Research in Commerce and Managment 1: 40-57.

8. Naidu S (2008) Supply chain management of fruits and vegetables.

9. Gundewadi BB (2013) Role and Performance of Cold Storages in Indian Agriculture. Int. J Sci Res 2: 323-323. 